\title{
БІОГРАФІЯ ФІЛОСОФА ЯК ПАРАДОКС
}

\section{B.I. Менжулін}

В процесі дослідження ролі біографічних чинників в історико-філософському пізнанні ми зіткнулися з уявленням, згідно з яким життя філософа абсолютно нічого не дає для розуміння його вчення, отже їх треба розглядати окремо. В цій статті ми спробуємо показати, що подібне уявлення, хоч воно і $є$ досить поширеним (в сучасній англомовній літературі воно отрнмало спеціальну назву - компартменталізм ${ }^{1}$ ) і навіть має певну (досить велику) рацію, потребуе істотної корекції. Зробити це ми спробуємо шляхом огляду трансформацій, яких зазнав образ філософії впродовж її тривалої історії. 3 нашого погляду, радикальний (i, відповідно, не дуже перспективний) компартметалізм породжений тим, що його виразники «розглядають філософію у відповідності із концепцією, успадкованою від Середніх віків та Нового часу, як суто теоретичну і абстрактну діяльність» $[2$, с.62], хоча насправді так було далеко не завжди.

На думку автора щойно наведеної цитати (відомого французького історика філософії П. Адо), за часів античності домінував зовсім інший образ філософії: для давніх вона була не тільки і не стільки чисто теоретичною активністю, скільки певним образом життя, певною системою духовних вправ, ціллю (телосом) яких було самоперетворення, вдосконалення людини, досягнення нею щасливого та доброчесного життя. Як твердив Сенека, «немає ані філософії без доброчесності, ані доброчесності без філософії. Філософія є турботою про досягнення доброчесності за допомогою самої доброчесності» [24, с. 356]. Пізнавальна настанова («пізнай себе») була лише однією із складових в процесі реалізації значно більш широкого - життєво-практичного -

\footnotetext{
${ }^{1} \mathrm{Biд} \mathrm{антлійського} \mathrm{«compartmentalisations} \mathrm{-} \mathrm{розділення} \mathrm{на} \mathrm{відсіки,} \mathrm{дроблення.}$
} 
завдання, яке полягало, як показав свого часу М. Фуко, у «турботі за себе» ${ }^{2}$. Основна проблема, що поставала перед філософом античності, полягала у з'ясуванні, що означає юити філософією. Для нас це може здатися дивним, але «Марка Аврелія називали „філософом“ ще до того, як дізналися, що він автор „Розмислів". Спосіб жсиття давав право називати людину „філософом“, незалежно від того, е у неї особлива „філософська теорія“" або ні» [8, с. 17].

Сучасний образ філософії як переважною мірою теоретичної діяльності суттєво позначається на характері її викладання та вивчення i, що для нас особливо важливо, на оцінці ролі, яку має відігравати в цих процесах усвідомлення чинників життево-біографічного порядку. «Антична філософія пропонуе людині мистецтво жити, а сучасна філософія постає перш за все, як конструкція технічної мови, що призначена для фахівців» [2, с. 279]. В наші часи вивчення філософії великою мірою перетворилося на абстрактно-теоретичний аналіз текстів, тобто, фактично кажучи, на філологію. Ми зовсім не збираємося піддавати сумніву те величезне значення, яке має аналіз текстів для філософської науки. Однак, як справедливо зазначае П. Адо, філологія «може стати для філософа небезпечною тією мірою, якою вона намагається бути самодостатньою і гальмувати його зусилля на шляху істинно філософського розмислу» $[3$, с. 60]. Абсолютизація текстуального виміру, зосередження на вивченні історії одних лише текстів $\epsilon$ свого роду вiдчужениям філософії від ії найдавнішого та, як нам здається, найавтентичнішого образу. В наші часи філософські тексти античності читаються, як правило, лише як безпосередні ретранслятори інформації стосовно певних вчень, понять, теорій їх авторів, тоді як насправді вони у більшості своїй були щільно пов'язані із життевими ситуаціями. Так, скажімо, Адо впевнений, що «помилка багатьох інтерпретаторів Аристотеля як раз полягала в тому, що вони забули, що його твори були [не систематичним викладом, а] навчальними зошитами. . . Різні logosi Аристотеля відповідають конкретним ситуаціям, що склалися внаслідок тих чи інших навчальних дебатів» $[2$, с. 59].

Навіть в такому жанрі античної філософської літератури, як коментування (тобто студіювання власне текстів), за думкою Адо, основна мета полягала не стільки у вивченні самого тексту, скільки в тому, щоб учень набув «непорушну впевненість в догматах школи, які мають регулювати його життя» [3, с.94]. Окрім того, заняття філософією

2 До речі, як вважае сучаснпй російсккий дослідник, поворот Фуко «від ,археології знання" та "генеалотії влади-знання" до практик „турботи за себе" був пов'язаний ... 3 трагічним особистим досвідом мислителя» $[8$, с. 15$]$. 
в античності дуже часто мали на меті досягнення того, що П. Адо називає конверсією (духовне обернення, перетворення). Наприклад, за думкою цього авторитетного історика, вчення Платона про ідеї не можна розглядати як суто теоретичний винахід: спочатку його автор пережив особисте духовне обернення (від світу тіней до світу ідей), а потім спробував здійснити аналогічну процедуру з цілим містом-державою. В цьому плані Платон не був поодиноким - після нього пошуки шляхів як до особистої конверсії, так і до реалізації філософських розмислів в громадсько-політичному житті не припиняються. Уявлення, згідно 3 яким заняття філософією можуть мати своїм продовженням активну політичну діяльність, відтворюеться в назві одного 3 філософсько-біографічних творів (нажаль, повністю втраченого) доби еллінізму - «Життя тих, хто перейшов від філософії до тиранічного та деспотичного правління» Герміпа. Однак ще більшого розвитку набуває тенденція ув'язувати філософські розмисли з індивідуальним життям. Фактично, в кожній філософській школі доби еллінізму розроблялися особливі духовні вправи, що відповідали обраному способу життя.

За влучним виразом П. Адо, античні філософські школи були свого роду «експериментальними лабораторіями» 3 вивчення життя [3, с. 10], $\mathrm{a}$, за словами одного 3 його однодумців (американця А. Девідсона), «вибір образу життя, екзистенційної настанови являе в певному роді специфіку кожної школи» $[3$, с. 155$]$. Інший сучасний американський дослідник вважає, що кожна елліністична філософська школа мала свій екзистенційний телос [29, с.21]. Кініки ратували за відкидання умовностей суспільного життя; перипатетики пропагували теоретично-споглядальне, дослідницьке життя; епікурейці - утримання від неприродних бажань (слава, багатство) заради збереження душевного спокою; скептики - досягнення стану атараксії через відмову від суджень; платоніки - екстатичне об'єднання із космосом, діалогізм, інтелектуалізм, життя за розумом та просвітлену останнім політичну активність. Ось, наприклад, як в своєму славетному «Сьомому листі» Платон говорить про те, з якою метою він вирішив відправитися у доленосну подорож на Сицилію: «Я нарешті схилився до того, що треба [їхати], якщо я тільки хочу бачити здійсненими свої думки... Мені було б дуже соромно перед самим собою, якби не виявилося, що я здатний лише на слова» [20, с. 479]. Лінія на духовне перетворення шляхом регламентації повсякденних життевих практик особливо чітко проводилася стоїками, які відкрито заявляли, що для них філософія «полягає не у викладанні абстрактної теорії, і ще менш-в екзегезі 
текстів, а в мистецтві життя» [2, с. 23]. Представники ціеї школи не тільки заявляли, що «порожніми $е$ розмови філософа, якщо вони не сприяють лікуванню хвороби душі» [2, с. 271], а й з великим ентузіазмом філософували 3 приводу того, чи можна класти ногу на ногу під час занять філософією. Отже, цілком логічно, що паралельно із заявами про те, що «школа філософа є лікарнею» [2, с. 344-345], стоӥк Епіктет виписував своїм учням «рецепти», як треба себе поводити на бенкетах або, скажімо, під час спектаклів, а один 3 його учнів (Марк Аврелій) постійно дбав про реалізацію норм стоїчної моралі у своїх щоденних політичних практиках. Прояв цієї настанови можна знайти і в творчості ще одного наближеного до стоїків мислителя класика античної біографістики Плутарха. У своїх славетних «Порівняльних життеписах» він намагався продемонструвати, яким чином уявлення, що сформувалися у того чи того політичного діяча (наприклад, Перікла, Алківіада, Александра) внаслідок його спілкування з тим чи тим філософом (Анаксагором, Сократом, Аристотелем відповідно), впливали на його вчинки. Плутарх віддавав перевагу аналізу вчинків навіть у випадку з постатями, що прославилися не тільки своїми політичними діями, а й власне думками. Наприклад, у зв'язку з такими двома політиками та одночасно мислителями, як Демосфен та Цицерон, Плутарх розкритикував свого колегу (Цецилія), який взявся аналізувати їх думки, ігноруючи їх життя та вчинки [21, с. 279]. Що стосується античної власне філософської біографістики, то в її розвитку важливу роль зіграли також тексти стоїка Панеція, в яких опис різних філософських шкіл постійно супроводжувався розглядом біографій їх представників.

3 урахуванням вищесказаного особливого значення набуває той факт, що на досить ранніх етапах розвитку античної філософії у її провідних представників, незважаючи на всі їх розбіжності, сформувався спільний ворог - софісти, тобто люди, які займалися лише вдосконаленням власної філософської мови, але не перетворювали у відповідності до ціеї мови власне життя. Для багатьох провідних мислителів античності не слова філософів, що можна було вичитати в їх творах або почути від інших, а безпосередне ознайомлення з їх життям вважалося головним джерелом справжньої філософської освіченості. «I все ж кориснішими, ніж книжки, були б для тебе живий голос і товаришування з розумними людьми, - повчав Сенека Луцілія. - Не став би Клеант точною подобою Зенона, якщо б він тільки чув його. Адже він ділив з ним життя, бачив приховане, спостерігав, чи живе Зенон у згоді із своїми правилами. I Платон, і Аристотель, і весь сонм мудре- 
ців, які потім розійшлися в різні сторони, більше почерпнули з звичок Сократа, ніж 3 його слів» $[24$, с. 47$]$.

Саме життя та діяльність першого та головного критика софістів Сократа слід вважати одним із найзначуших моментів, справжньою віхою в історії філософської біографістики. На жаль, про переважну більшість античних біографій ми знаємо лише з переказів, а оригінальні біографічні тексти, що дійшли до нас, належать майже повністю до доби Римської імперії. Тим не менш, з усіх філософських творів античності, що дійшли до нас у цілісному вигляді, першим за часом створення є Ксенофонтові «Спогади про Сократа». Так, перші спроби біографічного письма, як припускае відомий фахівець з даної проблематики А. Момільяно, були здійснені, ще в до-сократівські часи (у V ст. до н.е.) [40, с. 12]. Однак примітно, що інтерес перших біографів майже одразу спрямовується на життя та думки не будь-кого, а на попередників Сократа - мудреців, тобто людей, які прославилися як думками, так і вчинками. Збереглися повідомлення про те, що у V ст. до н.е. значною популярністю користувався текст під назвою «Бенкет семи мудреців» [40, с. 27]. В IV ст. до н. е., паралельно із зростанням ролі філософії та популярності індивідуальної освіти, біографічний жанр в Афінах набуває справжнього розцвіту, і великою мірою цей феномен пов'язаний саме із фігурою Сократа. Саме його послідовники були лідерами біографічного експериментування в IV ст. до н.е. $[40$, с. 46]. За доби еллінізму взагалі не було майже жодного біографа, який не займався би життєписами філософів - не тільки Сократа, а й Піфагора, Платона, Емпедокла, Зенона Елейського, Анаксагора, Діогена Синопського, Аристотеля та багатьох інших $[1$, с. 165$]$. Однак в контексті нашого дослідження особливе значення має увага численних античних біографів саме до Сократа, причому здебільшого як до взірцевого прикладу едності вчення та життя, дорійської гармонії слова $($ logos) і справи (ergon) [32, c. 1-2]. Саме через це представники багатьох філософських шкіл античності вели свій інтелектуальний родовід від Сократа, саме тому для численних поколінь філософів він став зразком для наслідування і свого роду праотцем або навіть тотемічним предком.

В історії філософії, зокрема й новітньої, є чимало свідоцтв того, що Сократ може служити свого роду тотемічним божеством, сакральною фігурою, у зв'язку з якою починае діяти містияна партиципация специфічний механізм архаїчного мислення, що був описаний Л. ЛевіБрюлем [13]. За таких умов ототожнення тієї чи іншої особи з Сократом майже автоматично слугуе доказом $\dddot{1}$ причетності до філософії, 
тоді як протиставлення Сократу $\boldsymbol{\varepsilon}$ натяком на те, що належність ціеї конкретної особи до племені справжніх філософів $\boldsymbol{\epsilon}$ сумнівною. Величезні магічні потенціали, які містить в собі можливість ототожнення із Сократом, прозорливо розгледів Ніцше, у якого деструкція образу праотця західних філософів стала одним 3 найважливіших елементів його загального наступу на західну метафізику як таку.

В історії філософії можна знайти чимало прикладів ототожнення або, навпаки, разототожнення нащадків Сократа 3 їх «праотцем», однак зараз ми хотіли би звернути увагу на те, що аналогія Сократа із тотемічним предком дозволяє краще зрозуміти одну принципову відмінність сократичної біографістики від того, що прийнято очікувати від біографії у сучасних академічних колах. Ми схильні вимірювати якість біографії за допомогою категорій «правда» або «брехня», тоді як Платон, Ксенофонт та їхні продовжувачі такого розмежування не проводили. Адже про тотемного предка розповідають не «правду» або «брехню», а міфи, які до цього розрізнення абсолютно нечутливі. «Ми не зрозуміємо, чим була біографія у IV ст. [до н. е.], - стверджуе Момільяно, - якщо не усвідомимо, що вона займала непевне (ambiguous) положення між фактом та уявою. У випадку з такою людиною, як Платон, та навіть 3 такою менш масштабною, але ніяк не простішою людиною, як Ксенофонт, ця непевність (ambiguity) була результатом свідомого вибору. Сократики експериментували з біографіями і ці експерименти мали на меті схопити не стільки реалії, скільки певні потенціали життя індивідів. Сократ - головний об'єкт їхньої уваги - був не стільки реальним, скільки потенційним Сократом. Він не був померлою людиною, життя якої треба переказати. Він був провідником до ще невідомих територій» [40, с. 46-47]. Відповідно, Платону ніщо не заважало не тільки черпати в сократівському життевому ідеалі силу та сміливість для реалізації власної життевої програми $[9$, с. 14$]$, а й проектувати на фігуру вчителя власні філософські концепції [3, с. 192], тобто використовувати біографію Сократа з метою трансляції власного вчення та переконання потенційних адептів в його перевагах. Отже, після Сократа його образ буття-у-світі перетворився на ідеал мудреця для багатьох генерацій філософів, а філософська біографія була не стільки формою історичного пізнання в нашому сучасному розумінні, скільки засобом оцінки самої філософії або формою створення певних моделей ідеального життя філософа, тобто, фактично, певних міфів.

Властивою міфу відсутністю зацікавлення у відділенні ідеального від реального можна пояснити, скажімо, і факт величезної популярності, що мали у античних біографів різноманітні плітки, анекдоти. 
Останні, так само як і цілісні біографії філософів, використовувалися їх авторами та ретрансляторами «здебільшого в якості зброї проти шкіл, з якими вони суперничали» [40, с. 84]. Навіть такий мислитель, як Аристотель, хоч він сам біографій не писав і в цілому був значно реалістичнішим за Платона, тим не менш дуже пінував анекдоти про життя своїх колег. Саме в колі послідовників Аристотеля сформувалася могутня школа філософської біографістики, представники якої не тільки задовольняли інтерес широкої публіки до життя видатних особистостей та різноманіття людських характерів, але і виконували зазначену вище освітньо-агітаційну функцію. Історично першим представником перипатетичної біографістики був Аристоксен. Останній спочатку вчився в школі Піфагора, який, за Діодором Сицилійським, визначив філософа як людину, що «прагне до звичаю та образу життя мудрої істоти» $[8$, с. 17]. Не виключено, що саме ця настанова, а також культ особистості вчителя, який домінував в піфагорійській школі, зумовили появу значного інтересу до біографії у Аристоксена, а вже через нього - в перипатетичній школі. Так чи так, але, досліджуючи біографії своїх старих (Піфагор, Архіт) та нових (Сократ, Платон, Аристотель) вчителів, Аристоксен намагався порівняти їх фiлософії шляхом зіставлення їх стилів життя, активно використовуючи при цьому такий вшанований Аристотелем прийом, як переказ анекдотів. Популярність, якою користувалися анекдоти у античних біографів, а також той факт, що у виборі героїв своїх оповідей вони були не завжди досить розбірливі, наштовхуе на думку, що «антична біографія виникла і розвивалася у відштовхуванні від монументальної історіографії, як породження відцентрових, антимонументалістських тенденцій елліністичної культури» $[1$, с. 176$]$. Так, можна погодитися 3 автором щойно наведеної цитати (С.С. Аверинцевим) в тому, що антична біографістика в цілому - «це свого роду „кунсткамера“, де Александр Великий або Епіктет можуть стояти поряд з будь-яким Тіллібором або Тимоном» $[1$, с. 176], однак, як нам здається, наведені вище міркування стосовно місця, яке посідав в античній біографістиці Сократ, дають підстави вважати, що античні біографії філософів можуть претендувати не тільки і не стільки на пізнавальну цінність або цікавість (що Аверинцев визнає), а й на досить велике моральне значення (що він заперечуе) [1, с. 176].

Оскільки багатьма античними біографами дані стосовно того чи іншого філософа наводилися не стільки 3 метою відтворити його реальне життя, скільки заради пропаганди (чи навпаки - деструкції) його філософії та заохочення (чи навпаки - відговорення) інших людей слі- 
дувати її принципам (як теоретичним, так і життевим), оцінки могли коливатися від абсолютної схвали (коли йшлося про власних кумирів), або до не менш однозначної засуди (по відношенню до представників ворожого табору). Факти могли рішуче змішуватися з фантазіями, оскільки малося на меті не інформування, а формувания читачів. $\mathrm{Ha}_{\text {- }}$ вчания філософії було нерозривно пов'язане із філософським вихованням і саме в такому сполученні (інформування як підстава для формування) філософська освіта являла собою фундаментальний компонент античної культури. П. Адо впевнений, що принципова різниця між філософією, як вона розуміється в наші часи, та образом, який вона мала в античності, полягає саме «у цій настанові по відношенню до формування» [3, с. 146]. Подібну формуючу освіту, в процесі якої відбувалося як навчання, так і виховання, греки називали paideia, тоді як для простого набуття технічних навичок у них було інше слово-banausos. He випадково, що відомий філолог-класик Вернер Єгер присвятив освітіяк-вихованню в античності свою головну працю («Paideia»), а Епіктет, коли йшлося про людину, яка отримала гарну філософську освіту, називав їі pepaideumenos, тобто «сформованою» (не тільки «навченою», а й «вихованою»). У сучасному українському слововжитку ця єдність дещо губиться: слово «освіта» нерідко ототожнюється 3 одним лише навчанням, тоді як «виховання» виступае як окрема процедура, що має здійснюватися поза межами філософсько-освітніх установ. Носіям англійської мови дещо простіше: слово education, так як i paideia у греків, означає і навчання, i виховання, тоді як для навчання у суто технічному смислі (banausos) є чіткий еквівалент - training (тренування). В межах сучасного «філософського тренінгу» основне значення має інформація, причому - якомога більш безособова, тоді як класичний образ філософії нерозривно пов'язаний із формуванням особистості.

Директор Центру біографічних та автобіографічних досліджень університету $L a$ Trobe (Австралія) Ричард Фредман у своїй великій методологічній статті, що була опублікована в профільному науковому журналі («Біографія») стверджує, що розщеплення цілісного (інформативно-формативного) образу філософської освіти відбувається лише наприкінці античної доби. Згідно з Фредманом, у книжці «Про життя, вчення та вислови славетних філософів» Діогена Лаерція (перша половина III ст. н.е.) можна знайти як повчально-формувальні, так і суто інформаційні або навіть відверто розважальні елементи, тобто тяжіння як до певного біографічного реалізму, так і до популярного белетризму $[31$, с.306]. На думку іншого сучасного англомовного до- 
слідника (Е. Кохрейна), Діогена Лаерція (поряд із св. Іеронімом) можна вважати одним 3 двох головних попередників всієї біографічної традиції доби гуманізму [28, с. 393-395]. Маючи на увазі певну «неупередженість» (тобто відстороненість від оціночних суджень) Діогена та схожих на нього авторів, відомий шведський дослідник античної біографістики I. Дюрінг називав їх «журналістами античності». До провідників цієї традиції Дюрінг зараховуе, окрім Діогена Лаерція, ще низку авторів, зокрема - представника перипатетичної школи Герміпа, який був автором не тільки вже згадуваного трактату про «Життя тих, хто перейшов від філософії до тиранічного та деспотичного правління», а й першої відомої біографії Аристотеля. Герміп, як і великий Стагірит, пікавився різними анекдотами та плітками, але як справжній представник свого часу (він діяв наприкінці III ст. н.е.) використовував подібні матеріали не стільки для доказу переваг традиції, до якої відчував найбільші симпатії, а для того, щоб розважати читачів [30, c. 464$]$.

Однак, якщо говорити про античність в цілому, ці тенденції навряд чи можна визнати магістральними. Об'єктивні умови для їх розвитку, якщо і існували, то не дуже довго: йдеться майже виключно про авторів, що діяли у III ст. н.е. Як показується у праці американської дослідниці П. Міллер «Біографія за часів пізньої античності: у пошуках святої людини», популярність «неупередженого», тобто суто інформаційного «філософського журналізму» тривала недовго, і згодом виховально-формувальна тенденція знов взяла гору, адке «протягом III та IV ст. [н.е.], коли язичницькі та християнські школи змагалися між собою за визнання в якості головного духовного стражу імперії, біографії набували характеру культових агіографій» [39, с. XIV].

Цілком природно також, що за доби Середньовіччя, коли активна фаза боротьби між язичництвом та християнством вже завершилася, агіографія святого стала ледь не єдино можливою формою життепису. Потреба у біографічних відмінностях та у біографіях власне


чних предків», фігури яких шанувалися в тому чи тому філософському «племені», прийшли численні, але, як правило, однотипні розповіді про святих, які лише іноді «доповнювалися такими випадковими прикрасами, як «Життя Ансельма», що було написане XII ст. Едмером» [43, с. 11]. Поновлення інтересу до біографії мало місце за часів Ренесансу в Італії. Всупереч педагогічним традиціям Середніх віків (Фома Аквінський вважав приклад найменш вагомою формою аргументації), гуманізм проповідував повернення до античної історії, ко- 
тра, як твердив флорентійський гуманіст Верджеріо, «наводить нам конкретні повчальні приклади, які багаторазово подавалися філософією. Один приклад показуе, що люди мусять робити, інші ж - що люди говорили та робили у минулому, і які практичні уроки ми можемо взяти 3 цього для теперішнього дня» (цит. по: [35, с. 15-16]). Іспанський гуманіст Антоніо де Гевара радив своїм читачам ставитися до «мудрого філософа та шляхетного імператора [Марка Аврелія] як до вчителя у юнацтві, як до батька в урядуванні, як до лідера у війні, як до провідника в експедиціях, товариша у праці, як до зразка у чеснотах, вчителя у навчанні, як до орієнтиру у власних амбіціях та як до суперника у справах» (цит. по: [35, с. 22]). Героями біографій, що їх написав ще один представник флорентійського гуманізму Джіаноццо Манетті [38], поряд із Данте, Бокаччо, Петраркою та Папою Ніколаєм V, стали також Сенека та Сократ. Як показуе сучасний американський дослідник спадщини Манетті, у своему творі «Життя Сократа» цей перший біограф великого афінянина у після-античні часи досить свавільно скористався різноманітними античними свідоцтвами 3 метою сконструювати новий образ Сократа, який міг би служити авторитетом та зразковим прикладом, моделлю (exemplum) для гуманістичного культурного проекту [36]. «Проби» французького гуманіста Монтеня просто переповнені описами життевих висновків, які автор впродовж своеі безперервної самоосвіти (само-формування) робив, пригадуючи то тут, то там випадки з життя давніх філософів. Адже, за його переконаннями, філософи давнини, «великі в науці, були ще величніші у всіляких справах» [16, с. 151]. Приклади подібної величі він знаходить переважною мірою не у головних теоретиків античності (Платона та Аристотеля), а у більш практичних мислителів - у тих самих Сенеки та Сократа. Монтень був впевнений, що краще за все Сократ вмів жити $[17$, с. 28], а одним 3 найголовніших життевих уроків, поданих Монтеню афінським шанувальником мудрості, була «приземленість» останнього, вміння насолоджуватися суто земними радощами, незважаючи ні на що, зокрема й на старіння $[17$, с. 356]. За можливість отримувати подібні уроки життєвої мудрості Монтень був особливо вдячний представникам такого жанру, як біографістика: «Ось чому Плутарх, - говорить автор „Проб“, - 3 усіх оглядів мій улюбленець. Я вже шкодую, що замість одного ми не маємо десятка Діогенів Лаерціїв чи що він не досить докладний і приступний. Мені не менш цікаво пізнати долю і життя цих великих навчителів світу, ніж розмаїття їхніх вірувань та марень» $[15$, с.99].

Однак період відродження повноцінного інтересу до життєво-пра- 
ктичних аспектів філософування тривав недовго. Уявлення про біографію як зразкову модель життя, яке тільки нещодавно зазнало ренесансу, почало руйнуватися вже у пізньому гуманізмі, коли стало приходити розуміння, що античні приклади насправді можуть не тільки вселяти оптимізм своєю взірцевістю, а й розчаровувати та навіть шокувати своєю непридатністю та неприйнятністю $з$ точки зору вимог сучасності $[43$, с.3]. 3 приходом Нового часу це питання лише загострилося. Якщо один із фундаторів Новочасової філософії Ф. Бекон ще говорив, що історики 3 рівним успіхом можуть займатися вивченням не тільки часових проміжків, що наповнені певними подіями, а й окремих осіб, життя яких може стати гідним прикладом для наслідування, то його власне біографічне дослідження (присвячене Генріху VII) було розкритиковане наступними поколіннями істориків як суто моралістичне і далеке від реального фактажу, тобто ненаукове [43, c. 1 2]. Інакше й бути не могло: війна 3 «ідолами», яку оголосив сам Бекон, неминуче вела до спроб встановлення табу на все, що хоч якимось чином нагадує сакралізацію життя будь-яких осіб, зокрема й філософів. На думку Фредмана, традиція асоціювати біографію з агіографією (i, відповідно, сприймати першу як ненаукову форму діяльності) припиняється лише у XIX-XX ст., коли паралельно із прогресом капіталізму, індивідуалізму та емпіризму на філософсько-біографічній сцені поряд із ідеальним мудрецем та святим знов з'являється живий філософ 3 його специфічною індивідуальністю [31, с. 308-309]. Однак впродовж XVII-XVIII ст. образ філософії як способу життя, тобто такого заняття, важливою складовою якого е біографія, піддається дуже значному затьмаренню. Особистість філософа ще можна помітити у медитаціях Декарта або в одному з найранніших творів Спінози («Трактат про вдосконалення розуму», на початку якого він пояснюе особисті мотиви, що спонукали його почати філософувати). Однак дуже скоро на передньому плані Новочасової філософії опиняються такі універсалістські, надособові та наджиттєві проекти, як філософія Ляйбніца, або, скажімо, Вольфа. За таких умов перевага віддаеться коротким інформаційним довідкам, які можна викласти у словнику. Одним з відоміших прикладів моди на представлення біографій у словниковому або енциклопедичному форматі став, скажімо, «Історичний та критичний словник» П. Бейля. Однак, на думку низки авторитетних сучасних дослідників, цінність цієї традиції з точки зору розвитку власне біографістики була дуже обмеженою: «оскільки в середині XVII ст., судячи з усього, була втрачена успадкована ще від античності моральна та освітня націленість біографії, залишалося дуже небагато напрямків, 
в яких міг би здійснюватися її розвиток» [43, с. 14]. Особливо це проявилося в галузі філософської освіти, яка впродовж цього періоду стає здебільшого суто інформаційною, а не формаційною, тобто такою, що дистанціюеться як від історій формування мислителів минулого, так і від виховання на цих прикладах тих, хто філософії тільки навчається. Характеризуючи ці тенденції, П. Адо зазначає, що «у вузькій перспективі університепів, оскільки йдеться про підготовку учнів до вивчення шкільної програми, яка дозволить їм отримати диплом чиновника та відкриє кар'єру, особистісний та суспільний зв'язок мусить неодмінно зникнути, щоб поступитися місцем викладанню, яке адресуеться усім, тобто нікому» $[3$, с. 96$]$.

Одну 3 причин цього зсуву П. Адо бачить в тому, що 3 приходом християнства, яке взяло практичне життя людини під своє пильне піклування, за філософією залишилася здебільшого одна лише теоретична діяльність [2, с. 62-63]. Однак своєю повторною «теоретизацією» (що розпочалася після Ренесансу) філософія, з нашого погляду, зобов'язана вже не християнству, а стрімкому підсиленню нового авторитету - науки. Складається враження, що ми маемо справу із остаточною перемогою компартменталізму, адже в модерному світі, де пануе наука, філософія більш не $є$ способом життя, зараз філософ зайнятий створенням універсальних теорій, а його життя - це виключно його приватна справа; філософа-мудреця замінив філософ-науковець, отже, його життя та його філософія можуть та мусять розглядатися роздільно. Однак, як нам здається, такий висновок був би дуже поспішним. Новочасовий розрив філософської теорії з філософською практикою був досить неоднозначним та неостаточним. Річ у тім, що насправді «у Нового часу було два витоки - гуманістичний та раціоналістичний. Модерна наука, шо народжується у перші декади XVII ст., затіняе та навіть спотворюе хронологічно більш ранній гуманізм Нового часу. Адже витоком останнього був зорієнтований на практику гуманістичний скептицизм «Проб» Монтеня, що з'явилися ще 1580 р.» $[12$, с. 67]. Відомий американський філософ, методолог та історик науки С. Тулмін впевнений, що «ще треба буде зрозуміти, чому ці дві традиції з самого початку стали розглядатися як конкуруючі, а не як такі, що доповнюють одне одного» і наголошуе на тому, що «якими б великими не були результати натурфілософських проривів Галілея, Декарта та Ньютона, відмова від Еразма та Рабле, Шекспіра та Монтеня також чревата певними втратами» (цит. по: [12, с. 68]). В цьому світлі позиція О. Валевського, який розпочинае своє дослідження з припущення, згідно з яким біографічне письмо «являе собою сполучення двох 
істотних для европейської культури оріентирів - раціоналізму та індивідуалізму» $[7$, с. 4], виглядає як свого роду самозаспокоення. Єдність раціоналізму та індивідуалізму, принаймні у випадку з біографістикою як складовою історико-філософського пізнання, $є$ не аксіомою, а тим, що треба довести. Більш драматичним, але, як нам здається, і більш реалістичним $є$ спостереження, яке робить інший сучасний філософ: констатуючи існування в історії філософії двох образів філософії (філософія як спосіб життя і як знеосіблена теорія), він зазначае, що «ці дві сторони філософії не завжди живуть мирно», а також знаходить необхідним попередити, що, абстрагуючись від цілісного образу філософії як єдності універсально-теоретичної та індивідуально-практичної діяльності, «ми перетворюемо її на квазі-науку та її позбавляемося» $[8$, c. 650]. Не виключено, до речі, що проблема стоїть ще гостріше: навіть якщо ми погодимось 3 думкою сучасного американського знавця історії та теорії біографічного письма про те, що в «прагненні до біографії.. . західне поняття індивідуальності інтегруеться з ідеалами демократії як альтернативи диктатурі та тиранії» [34, с. 2], з неї автоматично не випливає, що демократія, а, отже, і прагнення до біографії $\varepsilon$ одвічними. Історія того ж Заходу дае значно більш контроверсійну картину.

М. Хайдеггер з тривогою говорив про домінування об'єктивістського теоретизму в метафізиці як про «долю» Заходу. Однак його власний анти-біографізм, як нам здається, $\epsilon$ прикладом покірливого прийняття цієї «долі». Дійсно, довготривалі успіхи математизованого та деперсоналізованого природознавства виглядають остаточним вироком невмолимої долі, яка не залишае місця для філософії як способу життя, а заодно переводить філософську біографістику до розряду ледь не бульварного чтива. Аналогічна ситуація мала місце і в Середні віки, коли на зміну античному мудрецю прийшли теологи та схоласти. Тільки тоді практичну функцію у філософії відібрала релігія, а в модерному світі філософа-мудреця намагається замінити філософ-науковець, який хоче займатися створенням універсальних теорій, розглядаючи турботу за життя як виключно приватну справу. В рамках просвітницького проекту «індивідуальне редукується до здатності всезагального... накладати свою печатку на випадкове» [26, с. 194], однак Просвітництво, як показуеться у щойно процитованій праці, мае свою діалектику. В нашому випадку вона проявляється в тому, що навіть 3 приходом Нового часу та Просвітництва біографічно-екзистенційний елемент не зникає з філософії остаточно, а лише зазнае певної маргіналізації. Індивідуально-практична настанова, яка жкивила античну 
мудрість та ренесансний гуманізм, продовжуе існувати, і це зовсім не випадково, адже прохід між Сциллою обскурантизму (Середні віки) та Харибдою сцієнтизму (Новий час) рівною мірою чреватий розколом образу філософії як єдності знання та мудрості.

Уявлення, згідно 3 яким впродовж останніх століть «лише окремі міцні спалахи екзистенційно-персоналістського духу вказують на споконвічний образ цілісної філософії [8, с. 651], мае певну рацію, однак треба не забувати, що йдеться про дуже міцні спалахи. Навіть про таких досить сцієнтично налаштованих мислителів Нового часу, як, наприклад, Декарт, Спіноза, Локк або Юм, «можна сказати, що вони та їх послідовники намагаються створити систему, яка відповідає на засадові питання існування» [42]. Великий інтерес до особистого виміру виявляли представники романтичного руху. Тим більш це стосуеться багатьох провідних філософів більш пізніх епох. Скажімо, за А. Бергсоном, «космос у своєму бутті рівний переживанням живої людини, і їі світогляд, як витлумачення сенсу людського існування, переносить центр ваги на élan vital (життєвий порив)», 3 точки зору Г.Зиммеля, «остання основа світогляду міститься у житті» (див.: [23, с.32-37]). Молодий Маркс, пишучи докторську дисертацію, що була присвячена нібито абсолютно віддаленій від його життя темі («Відмінність натурфілософії Демокрита від натурфілософії Епікура»), насправді, як вважає його сучасний французький біограф, розробляв «основи власної концепції ролі філософа в суспільстві» [5, с. 52], а, наприклад, останне прохання, з яким звернувся Вітгенштайн незадовго перед своєю смертю до жінки, яка за ним доглядала, полягало в тому, щоб вона передала його друзям, що в нього було прекрасне життя [37, c. X].

Ще більш відверто виражений екзистенційний елемент у філософських пошуках таких видатних постатей, як, скажімо, Паскаль, К'еркегор або Ніцше. Дійсно, за своїх часів вони виглядали досить маргінально, однак згодом з'ясувалося, що для подальшого розвитку філософії вони значили куди більше, ніж їх численні сучасники, яких Шопенгауер піддавав нищівній критиці в статті «Проти університетської філософії». Про них же Генрі Торо (ще один «філософ-маргінал») говорив, що «у нас є професори філософії, але не філософи» [25, с.6]. Проти такої ситуації, коли основна ціль освіти (формування особистості) підміняється другорядною (професійним інструктуванням) рішуче виступив Ніцше у циклі лекцій під загальною назвою «Щодо майбутнього наших освітніх закладів» (див.: $[41$, с. 70$]$ ). Навіть такий взірець науково-професійної само-ідентифікації філософа, як Кант, не 
поважав багатьох свої колег по професорському цеху за «артистизм розсудку» (штучний відрив філософської теорії від практики). Так, сам Кант, підпорядкувавши теоретичний розум розуму практичному, спромігся своїм неповторним життям продемонструвати, що «можна бути професором та творити велику філософію» [42]. Однак це не було зрозуміло до нього, коли провідні філософські системи створювалися поза межами академії. Не стало це правилом і після Канта. На думку М. Шелера, схоластична форма викладання філософії, яка домінувала в університетах аж до початку XX ст., не мала жодного впливу на загальну духовну освіту. Про останню подбали «геніальні оригінали по той бік університету», завдяки яким, як вважає Шелер, і виникла вся сучасна філософія [27, с. 68].

Всіх цих «оригіналів»-Спінозу, Паскаля, К'єркегора, Ніцше, Торо, Шопенгауера та багатьох інших по-справжсньому видатних філоcogis-споріднюе між собою те, що всупереч домінуючим в їх часи уявленням, вони вважали філософію особистою екзистенційною справою. Про принципову самобутність філософування можна почути не тільки від давніх (наприклад, Сенека повчав Луцілія: «Соромно. . . набиратися мудрості з посібника. „Так сказав Зенон“. - А ти сам? - „А це було сказано Клеанфом“. - А ти-то? До яких пір будеш під началом у інших? Командуй сам, скажи слово, гідне пам'яті. Виречи щонебудь від себе» $[24$, с. 128]), а й від модерних мислителів. У своій інавгураційній лекції «Похвала філософії, що була прочитана в Колеж де Франс 1953 р., М. Мерло-Понті наголошував на тому, що «філософія пробуджуе нас до того проблематичного, що е в світі і в нас, причому таким чином, щоб ми назавжди відмовилися шукати рішення „у записах вчителя"» (цит. по: [3, с. 73]). Однак $є$ пункт, в якому усі «філософи-оригінали», нехай як завжди - кожен на свій манер, але все ж таки слідують прикладу свого спільного вчителя (Сократа), який «не дбав про те, про що турбується більшість людей, ... не йшов туди, де не міг принести ніякої користі..., а йшов туди, де ... міг зробити кожному... найбільше добро, намагаючись переконати кожного ... не турбуватись про свої справи раніше і в більшій мірі, ніж про себе самого» [19, с. 45$]$.

Вслід за Сократом філософи неодноразово демонстрували цю схильність до переходу від життя за нормами соціуму до життя, унормованого їх власною філософією. Як показує А. Кожев в одному з своїх трактатів, коли політична дія кличе за собою відмову від власної філософії, філософ, як правило, відмовляеться від цієї дії [11, с. 370$]$. у решти людства це, зрозуміло, викликало і продовжуе викликати 
серйозні побоювання, а нерідко навіть і ворожість. Філософська самобутність по відношенню до загальновизнаного життєустрою, до звичних поглядів та поведінки (тобто того, що скептики називали bios) відчутно зачіпае не-філософів. Тому цілком природно, що, скажімо, у комічних та сатиричних авторів античної доби філософи, як правило, «постають дивними, якщо не небезпечними персонажами» $[2$, с. 242]. Тільки висміюванням справа не вичерпуеться: суд над Сократом продемонстрував, наскільки трагічних форм може набувати конфлікт між унікальною інтелектуально-біографічною лінією філософа та «біосом» соціуму, який його оточуе. Тим не менш, філософи продовжують (більш або менш відверто та наполегливо) слідувати цьому небезпечному зразку, принаймні саме прийняття такої життевої стратегії давало К'єркегору надію на те, що на його могилі напишуть «Той, єдиний».

3 іншого боку, в історії філософії можна знайти чимало прикладів, коли ця фундаментальна самобутність філософа приховується. «Все глибоке любить маску» [18, с. 272],- твердив Ніцше, головний ворог якого (Сократ), будучи сам під маскою, став маскою для тих, хто мав потребу сховатися за ним [2, с. 92]. Платон та численні сократики доби античності, або, скажімо, К'єркегор - ось далеко не повний перелік мислителів, які приховували свою індивідуальність за допомогою образу, що був створений Сократом. Французькі персоналісти (сама назва цієї течії походить від латинського слова persona, тобто маска) виступали за те, що особистість $є$ трансцендентною по відношенню до індивідуального, а витоком такої філософії та своїм вищим ідеалом особистості називали все того ж Сократа (див., напр.: $[14$, с. 7,30$]$ ). Роль тотемічної маски довелося виконати і ще декільком мислителям 3 нестандартною біографією.

В історії культури можна знайти щілу низку масштабних культурних рухів, що об'єднували індивідів, які орієнтувалися на життєвоінтелектуальні моделі, що асоціювалися із тим чи іншим філософом. Наприклад, Ніцше став маскою для тисяч, якщо не мільйонів ніцшеанців. Наслідування вченням та життям таких «володарів умів», як, скажімо, Епікур, Вольтер, Толстой, трансформувалося у такі моделі життя для багатьох людей, як епікурейство, вольтер'янство та толстовство. Той факт, що подібні рухи надихалися не тільки думками зазначених мислителів, а і їх біографіями, знайшов відображення, наприклад, в статті «Вольтер'янство» у «Словнику сучасної російської мови», в якій йдеться, по-перше, про «вольтер'янство» як «світогляд, що заснований на філософських поглядах Вольтера», а, по-друге, про 
«вольтер'янця» як «вільнодумну людину» $[10$, с. 7$]$.

Важливо зазначити також, що майже всі без виключення рухи такого роду беруть за взірець досить штучний, далекий від реальності образ. Наприклад, дослідники історії вольтер'янства в Росії підкреслюють, що йдеться про «світовідчуття та форму суспільної поведінки, що надихалися не стільки творчістю Вольтера та його діяльністю, скільки тим його образом, який склався в Росії на межі XVIII та XIX ст. $[10$, с. 7]. Особливо далекими від реальності виявилися рецепції образу Ніцше, що створювалися всупереч його власним попередженням про те, що «будь-яка філософія є філософією авансцени», за якою приховується дешо інше [18, с. 400]. Деякі з наслідків буквального прочитання текстів Ніцше виявилися настільки небезпечними, що треба всерйоз говорити про те, що історія філософії, особливо - історикофілософська освіта, ніяк не можуть обмежуватися численними масками Ніцше, що з'являються на авансцені його творів, але також мусять шукати приховану за ними індивідуальність.

У будь-якому випадку, той факт, що таким оригіналам, як Сократ, Платон, К'еркегор, Ніцше, знадобилося «маскуватися», вказуе на те, що одного лише перетворення на одинака, який, подібно Г. Торо, усамітнюеться у лісі, зовсім недостатньо для народження унікальної філософської одиничності. Парадокс біографії філософа полягае в тому, що своїм суто індивідуальним шляхом він крокуе до всезагального. Усамітнення філософа $е$ принциповим кроком у напрямку до універсальності. На тлі усіх своїх індивідуально-біографічних особливостей, філософ прагне сягнути загальнозначного. Характерно, наприклад, що той же самий Г. Риккерт, який був впевнений, що «філософія не мусить мислити лише мислення i, в якості логіцизму, ставати ворожою по відношенню до повноти життя» [23, с. 222], тим не менш, закінчив свою книжку про філософію життя заявою, що хотів у ній говорити «лише про широко розповсюджені думки, а не про особистості окремих мислителів» $[23$, с. 238].

Отже, постійно слід враховувати, що філософія не тільки глибоко пов'язана з біографією, а й весь час намагається бути від неї автономною. 3 одного боку, всі ідеї певним чином вкорінені у історичному, соціальному та біографічному контексті, однак філософського статусу набувають лише ті 3 них, які «виявляються настільки могутніми, що трансцендують за межі свого часу та місця» [33, с.6]. Заповітна мрія філософів майже усіх часів - побачити світ sub specie aeternitatis (під кутом зору вічності), отже, їх робота «втрачає свій сенс, якщо виявляється неможливим 3 хаосу переживань теоретично випрацювати 
космос» [23, с. 212]. Дещо перефразуючи Т. Адорно, можна сказати, що філософія продовжуе свое існування лише тому, що ризикуе продовжувати керуватися ілюзорною надією на те, що все одиничне може бути розшифроване як ціле [4, с. 22]. Отже, не випадково, що саме філософи-персоналісти рішуче критикували індивідуалізм. Представники багатьох інших течій, наслідуючи Сократу, присвячують своє життя оволодінню «мистецтвом помирати», яке полягае «в тому, щоб перейти від бачення речей, в якому беруть гору індивідуальні пристрасті, до уявлення світу, яке керується універсальністю та об'ективністю думки» $[2$, с. 45]. Головна причина цього полягає в тому, що «смерть переважною мірою $е$ те, що найтіснішим чином пов'язане як з індивідом, якого вона наздоганяе, так і з повною безособовістю або „зовнішністю" по відношенню до нього. В цьому плані вона і $€$ думка, оскільки „мислити“ як раз і означає аскетично рухатися до точки, де індивіда пронизуе безособова непричетність, яка до того ж $\varepsilon$ його справжнім Буттям» [6, c. 23].

В цьому контексті цілком правдоподібно звучить, наприклад, повідомлення Порфирія, згідно з яким його вчитель та послідовник Платона Плотин завжди відчував сором від того, що жив у тілесному вигляді, а також уникав розповідати про своє походження, ніколи не святкував та нікому не називав дня свого народження. Однак уваги заслуговуе і інше повідомлення стосовно Плотина, що знаходимо у того ж Порфирія: «а між іншим, дні народження Сократа та Платона, нам відомі, він відзначав» [22, с. 428]. Окрім того, Плотин любив розповідати про свого безпосереднього вчителя (Амонія), зокрема про величезну радість від першої зустрічі з ним.

Отже, видається, що настанова філософа на універсальність та знеосібленість не є тотальною. Тут, скоріше за все, ми зустрічаемось 3 головним утрудненням, що постае перед біографом фiлософ $а$, саме тут ми маємо справу з однією з найпринциповіших відмінностей суто філософсько-біографічної роботи від того, чим займаються біографи представників інших видів людської діяльності. Філософ плекае свою самобутність і одночасно маскуе їі. Він прагне аподейктичності, але робить це надзвичайно індивідуальним чином, бо $є$ істотою, «яка часто біжить від самої себе, часто боїться себе, але яка є надто питливою для того, щоб постійно знов ... не повертатися до себе» [18, с. 401]. Саме наполегливе відхилення від звичних форм індивідуальності заради справжньої універсальності (а не звичайної банальності) робить життя філософа по-справжньому унікальним і неповторним. Нехтування цією діалектикою перетворюе таку високу справу, як філософія, 
на таке дуже усереднене заняття, як професія.

\section{1 Бібліографія}

[1] Аверинцев C.C. Плутарх и античная биография: К вопросу о месте классика жанра в истории жанра. - М.: Наука, 1973.

[2] Адо П. Духовные упражнения и античная философия. - М.: Издво Степной ветер; СПб.: ИД Коло, 2005.

[3] Адо ПI. Философия как способ жить: Беседы с Жанни Карлие и Арнольдом Дэвидсоном.-М.: Изд-во Степной ветер; СПб.: ИД Коло, 2005.

[4] Адорно Т.В. Негативная диалектика. - М.: Науч. мир, 2003.

[5] Аттали ЖК. Карл Маркс: Мировой дух. - М.: Мол. гвардия, 2008.

[6] Бадъю А. Делёз: Шум бытия. - М.: Логос-Альтера, 2004.

[7] Валевский А.Л. Основания биографики. - К.: Наук. думка, 1993.

[8] Визгин В.П. На пути к другому: От школы подозрения к философии доверия. - М.: Языки славянской культуры, 2004.

[9] Виндельбанд В. Платон.-К.: Зовнішторгвидав України, 1993.

[10] Вожди умов и моды: Чужое имя как наследуемая модель жизни. - СПб.: Наука, 2003.

[11] Кожев А. Тирания и мудрость // Кожев А. Атеизм и другие работы. - М.: Праксис, 2006. - С. 323-386.

[12] Крічлі С. Вступ до континентальної філософії. - К.: Стилос, 2008.

[13] Леви-Брюль Л. Сверхъестественное в первобытном мышлении. М.: Педагогика-пресс, 1994.

[14] Леруа Ж. Избранное: Персонализм. - М.: РОССПЭН, 2004.

[15] Монтень М. Проби. - Книга друга. - К.: Дух і літера, 2006.

[16] Монтень М. Проби. - Книга перша. - К.: Дух і літера, 2005.

[17] Монтень М. Проби.-Книга третя. - К.: Дух і літера, 2007. 
[18] Нuише $\Phi$. По ту сторону добра и зла: Прелюдия к философии будущего // Ницше Ф. Сочинения: В 2 т.-Т.2.-M.: Мысль, 1990. - C.238-406.

[19] Платон. Апологія Сократа // Платон. Діалоги.-Х.: Фоліо, 2008. - C. 21-51.

[20] Платон. Письма // Платон. Собрание починений: В 4 т. - Т. 4.М.: Мысль, 1994. - С. 460-516.

[21] Плутарх. Сочинения.-М.: Худож. лит., 1983.

[22] Порфирий. Жизнь Плотина // Диоген Лаэртский. О жизни, учениях и изречениях знаменитых философов. - М.: Мьсль, 1986. C. $427-440$.

[23] Pиккерт Г. Философия жизни. - Мн.: Харвест; М.: АСТ, 2000.

[24] Сенека Л.-А. Моральні листи до Луцілія.-К.: Основи, 1995.

[25] Торо Г.-Д. Уолден, или жизнь в лесу. - М.: Наука, 1979.

[26] Хоркхаймер М. Диалектика Просвещения: Философские фрагменты.-М.: Медиум; СПб.: Ювента, 1997.

[27] Шелер M. Университет и народный университет // Логос. 2005. - o 6 (51). - С. 60-97.

[28] Cohrane E.W. Historians and Historiography in the Italian Renaissance. - Chicago: Chicago University Press, 1981.

[29] Conant J. Philosophy and Biography // Wittgenstein: Biography and Philosophy. - Cambridge: Cambridge University Press, 2001.- P. 1650.

[30] Döring I. Aristotle in the Ancient Biographical Tradition.Göteborg: Elanders Boktryckeri Aktiebolag, 1957.

[31] Freadman R. Genius and the dutiful life: Ray Monk's Wittgenstein and the biography of the philosopher as sub-genre: (Critical Essay) // Biography. - 2002.-Vol. 25. - No 2. - P. 301-342.

[32] Gadamer H.G. Logos and Ergon in Plato's Lysis// Gadamer H. G. Dialogue and Dialectic: Eight Hermeneutical Studies on Plato. - New Haven and London: Yale University Press, 1980. - P. 1-20. 
[33] Gutek G.L. Cultural foundations of education: a biographical introduction. - New York - Toronto: Macmillan, 1991.

[34] Hamilton N. Biography: A Brief History.-Cambridge, Mass.; London, England: Harvard University Press, 2007.

[35] Hampton T. Writing from history: the rhetoric of exemplarity in Renaissance literature. - Ithaca and London: Cornell University Press, 1990.

[36] Hankins J. Manetti's Socrates and the Socrateses of antiquity [Eлектронний ресурс] // Harvard University's DASH (Digital Access to Scholarship at Harvard) repository. - 2008. - Режим доступу: http://nrs.harvard.edu/urn-3:HUL.InstRepos:2961810

[37] Klagge J.C. Editor's Preface // Wittgenstein: Biography and Philosophy. - Cambridge: Cambridge University Press, 2001. - P. ix-xvii.

[38] Manetti G. Biographical writings. - Cambridge, Mass.: Harvard University Press, 2003.

[39] Miller P.C. Biography in Late Antiquity: A Quest for the Holy Man.Berkeley: University of California Press, 1983.

[40] Momigliano A. The Development of Greek Biography. - Cambridge, MA: Harvard University Press, 1971.

[41] Safranski R. Nietzsche: A Philosophical Biography.-New York; London: W. W. Norton \& Company, 2003.

[42] Stanley Cavell Interview: Conversations with History [Електронний pecypc]. - Institute of International Studies, UC Berkeley, February 7, 2002.-Режим доступу: http://globetrotter.berkeley.edu/people2/Cavell/cavell-con3.html

[43] The Rhetorics of Life-Writing in Early Modern Europe: Forms of Biography from Cassandra Fedele to Louis XIV / T.F.Mayer and D.R. Woolf (Eds.). - Ann Arbor: The University of Michigan Press, 1995.

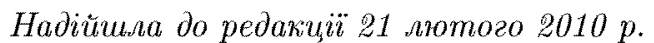

